\title{
Penggunaan Metilxantin pada Bayi Prematur dengan Apne Idiopatik
}

\author{
Susprawita Sari, Guslihan Dasa Tjipta, Dachrul Aldy
}

\begin{abstract}
Apne idiopatik pada bayi prematur terjadi tanpa faktor predisposisi yang teridentifikasi. Insidens apne idiopatik bervariasi, berbanding terbalik dengan usia gestasi. Awitan apne idiopatik biasanya terjadi pada hari kedua sampai hari ketujuh kehidupan, jarang pada hari pertama. Diagnosis dibuat berdasarkan gejala klinis. Apne pada bayi prematur yang bukan disebabkan oleh faktor yang teridentifikasi dapat diobati dengan metilxantin (kafein, teofilin). Metilxantin merangsang ventilasi melalui mekanisme sentral atau dengan peningkatan kekuatan diafragma. Kafein lebih disukai daripada teofilin karena kafein mempunyai beberapa keuntungan dan efek samping yang lebih sedikit. Pemberian obat harus disertai monitoring konsentrasi plasma dan klinis yang hati-hati.
\end{abstract}

Kata kunci: apne idiopatik, prematur metilxantin

$\mathcal{A}$ pne pada bayi prematur merupakan pola pernafasan abnormal yang ditandai dengan henti nafas lebih dari 20 detik, atau kurang dari 20 detik namun disertai bradikardia, sianosis, ${ }^{1-3}$ atau perubahan tonus otot. ${ }^{4,5}$ Pada bayi prematur, apne idiopatik jarang timbul pada hari pertama kehidupan, biasanya terjadi pada hari kedua sampai ketujuh. ${ }^{1,3,5}$ Apne yang timbul segera setelah lahir menandakan adanya penyakit lain. ${ }^{6}$ Prevalensi apne pada bayi prematur sebesar $25-50 \%, 4,5$ meningkat dengan berkurangnya usia kehamilan. ${ }^{7,8}$ Handerson-Smart menemukan bahwa serangan apne terjadi pada $78 \%$ bayi dengan usia kehamilan 26-27 minggu, 75\% pada usia kehamilan 2829 minggu, 54\% pada usia kehamilan 30-31 minggu, $14 \%$ pada usia kehamilan 32-33 minggu; dan 7\% pada usia kehamilan 34-35 minggu. ${ }^{9}$

Diperkirakan sekurang-kurangnya 50\% bayi yang bertahan hidup dengan berat kurang dari 1500 gram saat lahir mengalami episode apne dan harus diterapi

\footnotetext{
Alamat korespondensi :

Dr. Guslihan Dasa Tjipta, Sp.A(K), dr. Susprawitasari

Bagian Ilmu Kesehatan Anak FK USU/RS HAM Jalan Bunga Lau No. 17

Telepon : (061) 8361721, Fax : (061) 8361721 Medan
}

dengan dukungan ventilasi atau medikamentosa. ${ }^{1,4}$

Sejumlah teori tentang etiologi dihubungkan dengan tipe apne yaitu tipe sentral, tipe obstruktif dan tipe campuran; ${ }^{1,9,10}$ meskipun patogenesisnya belum jelas. ${ }^{7}$ Apne pada bayi prematur yang bukan disebabkan oleh faktor-faktor pencetus yang teridentifikasi dapat diobati dengan metilxantin (teofilin, kafein), ${ }^{9,11,12}$ yang dilaporkan dapat merangsang usaha bernafas. ${ }^{2,4,13}$ Obat ini telah digunakan dalam praktek klinik untuk menurunkan kejadian apne sejak awal 1970.,7 Teofilin dan kafein merupakan obat yang paling sering diresepkan pada perawatan neonatal intensif, walaupun mekanisme kerja secara spesifik masih belum diketahui. ${ }^{2,4,7}$

\section{Patofisiologi apne pada bayi prematur}

Patofisiologi apne pada bayi prematur berkaitan dengan kontrol abnormal pernafasan akibat imaturitas sistem neuron brain stem. ${ }^{3,4,9,14}$ Teori ini didukung oleh fakta bahwa bayi prematur dengan serangan apne menunjukkan waktu konduksi brain stem yang lebih lama dibandingkan kontrol. ${ }^{8,9}$ Faktor lain yang mempengaruhi penurunan usaha inspirasi pada bayi prematur adalah penurunan aktifitas refleks per- 
Sari Pediatri, Vol. 6, No. 3, Desember 2004

nafasan, ${ }^{9}$ kelemahan diafragma, dan dinding dada yang sangat lunak. ${ }^{4,8}$

Neuron khusus di medula ventralis mendeteksi tekanan parsial $\mathrm{CO} 2$ arteri $(\mathrm{PaCO} 2)$ dan $\mathrm{pH}$. Kadar $\mathrm{CO} 2$ darah merupakan stimulus yang paling berpengaruh terhadap usaha bernafas. Bayi dengan apne mengalami gangguan kemampuan kemoreseptor medula dalam mendeteksi peningkatan nilai CO2. Kegagalan bayi prematur untuk mempertahankan hiperventilasi sebagai respons guna mengatasi hipoksemia dapat menjadikan kontrol respirasi menjadi tidak stabil dan hal ini mengawali atau memperburuk episode apne. Sel-sel pada badan karotid mendeteksi $\mathrm{PaO} 2$ dan $\mathrm{PaCO} 2$. Selain keberadaan tekanan parsial O 2 fetal 25$30 \mathrm{mmHg}$, hanya dibutuhkan sedikit tekanan $\mathrm{O} 2$ untuk respirasi yang dikendalikan kemoreseptor di dalam uterus, karena pertukaran gas disempurnakan oleh plasenta. Setelah kelahiran, kemoreseptor badan karotid harus menggantikan batas fungsional menjadikan $\mathrm{PaO} 2$ lebih tinggi. Ketika konsentrasi $\mathrm{O} 2$ inspirasi rendah, bayi prematur dan cukup bulan menanggapinya dengan kenaikan ventilasi selama menit pertama, kemudian diikuti dengan penurunan ventilasi selama 2 atau 3 menit, terkadang pada masa istirahat terutama selama REM aktif. ${ }^{4}$

Pada masa neonatus walaupun stadium tidur sulit didefinisikan, episode apne kebanyakan terjadi selama tidur REM, ${ }^{9}$ ketika ada ketidakseimbangan antara frekuensi pernafasan dan volume tidal. ${ }^{4} \mathrm{Hal}$ ini ditunjukkan pada 50\% dari semua episod apne; baik sentral apne yang didahului atau diikuti oleh adanya obstruksi dan akhirnya menimbulkan apne campuran..$^{4,7}$ Obstruksi jalan nafas atas menimbulkan episode apne, saat tekanan negatif faring selama inspirasi dapat mengakibatkan faring atau laring kolaps. Obstruksi ini merupakan konsekuensi penyempitan jalan nafas akibat fleksi leher. ${ }^{4,9}$

Episode apne berhubungan dengan bradikardia, terjadi penurunan denyut jantung sebesar kurang dari 80-100 kali permenit, ${ }^{9}$ tetapi kadang-kadang didefinisikan sebagai penurunan denyut jantung lebih dari $30 \%$ di bawah nilai denyut jantung terendah. ${ }^{4}$ Refleks bradikardia terjadi secara sekunder sebagai akibat perangsangan hipoksia pada kemoreseptor badan karotid atau efek langsung dari hipoksia pada jantung. ${ }^{4,9}$ Bradikardia dapat terjadi pada pengisapan nasofaring, defekasi, dan menangis; tetapi hanya $14 \%$ bradikardia yang tidak berkaitan dengan apne. ${ }^{9}$

\section{Diagnosis}

Diagnosis apne pada bayi prematur ditegakkan bila beberapa kondisi lain yang muncul bersama dengan apne, seperti infeksi, gangguan metabolik, dan penyakit jantung, telah disingkirkan. Diagnosis bisa dibuat berdasarkan gejala klinis, walaupun hasil studi menunjukkan bahwa sejumlah besar persentase episode apne lebih dari 20 detik tidak dicatat oleh perawat. Oleh karena itu monitoring kardiorespiratorik, saturasi O2 dengan tekanan O2 transkutaneus (PO2), harus digunakan bersamasama pada bayi prematur (masa gestasi kurang dari 35 minggu), dan juga pada bayi cukup bulan dengan penyakit lain. ${ }^{4}$

\section{Obat-obat metilxantin}

Derivat xantin terdiri dari kafein, teofilin dan teobromin, merupakan alkaloid yang terdapat dalam tumbuhan. Ketiganya merupakan derivat xantin yang mengandung gugus metil. Xantin sendiri ialah dioksipurin yang mempunyai struktur mirip dengan asam urat. Kafein adalah 1,3,7-trimetilxantin; teofilin adalah 1,3-dimetilxantin; dan teobromin adalah 3,7dimetilxantin. ${ }^{15,16}$

Teofilin, kafein dan teobromin mempunyai efek farmakologis yang sama. Obat-obat ini menyebabkan relaksasi otot polos terutama otot polos bronkus, merangsang SSP, otot jantung, dan meningkatkan diuresis. Teobromin tidak bermanfaat secara klinis karena efek farmakologisnya rendah. Berbagai efek farmakologi metilxantin dapat diterangkan dengan 3 macam dasar kerja pada taraf seluler yaitu (1) berhubungan dengan translokasi Ca intrasel; (2) melalui peningkatan akumulasi senyawa siklis nukleotid, terutama siklik AMP dan siklik GMP; dan (3) melalui blokade reseptor adenosin. ${ }^{15,16}$

Metilxantin cepat diabsorpsi setelah pemberian per oral, rektal, atau parenteral. Sediaan dalam bentuk cair atau tablet tidak bersalut akan diabsorpsi secara cepat dan lengkap. Absorpsi juga berlangsung lengkap untuk beberapa jenis sediaan lepas lambat. ${ }^{15,16}$ Eliminasi metilxantin terutama melalui metabolisme dalam hati. Sebagian besar diekskresi melalui urin dalam bentuk asam metilurat atau metilxantin. ${ }^{15,16,17}$ Kurang dari 20\% teofilin dan 5\% kafein akan ditemukan di urin dalam bentuk utuh. ${ }^{16}$ 
Sari Pediatri, Vol. 6, No. 3, Desember 2004

\section{Penggunaan metilxantin pada bayi prematur dengan apne}

Pengobatan medis pada bayi prematur dengan apne dipertimbangkan bila jumlah episode apne $10 \mathrm{kali}$ atau lebih sehari, atau bila bayi berespons lambat terhadap stimulasi taktil atau yang membutuhkan bag and mask ventilation. Dalam hal ini, penggunaan metilxantin direkomendasikan. ${ }^{4}$ Mekanisme kerja metilxantin masih belum jelas, diperkirakan dapat meningkatkan sensitivitas kemoreseptor terhadap CO2, kekuatan otot respirasi, dan eksitasi susunan saraf pusat. ${ }^{2}$

\section{Kafein}

Kafein merupakan derivat metilxantin yang kini sering digunakan untuk mencegah atau mengurangi episode apne pada bayi prematur. ${ }^{12,18}$ Pada kebanyakan unit neonatus, kafein lebih disukai daripada teofilin oleh karena kafein memberikan indeks terapeutik yang lebih besar, ${ }^{10,18,19}$ stimulasi sentral yang lebih baik, pemberian satu kali per hari dengan fluktuasi yang lebih sedikit di dalam konsentrasi plasma, dan efek samping yang lebih sedikit. ${ }^{1,2,7,20,21}$ Kafein lebih aman terhadap denyut jantung, ${ }^{20}$ ekskresi natrium urin, gejala saluran cerna dan tingkah laku. ${ }^{18}$

Kekuatan kafein sebagai stimulan SSP dibandingkan teofilin tidak diketahui. Teofilin dapat menyebabkan kejang pada konsentrasi plasma yang lebih rendah daripada kafein. Sekresi asam lambung dan pepsin meningkat pada pemberian kafein per oral atau parenteral. Distensi abdomen yang sementara dijumpai, tetapi tidak dijumpai muntah atau diare pada konsentrasi terapeutik. ${ }^{21}$ Pada bayi, imaturitas sistem enzim sitokrom P-448/450 memperpanjang metabolisme kafein, mengakibatkan waktu paruh eliminasi yang lebih panjang. Oleh karena itu dianjurkan dosis satu kali perhari. Metabolisme dipercepat oleh maturitas sistem enzim, dan pada usia 9 bulan metabolisme kafein sama dengan orang dewasa. ${ }^{21}$

Masa paruh kafein lebih lama pada bayi prematur dibandingkan pada anak/dewasa. Pada bayi prematur masa paruh berkisar 31-132 jam. ${ }^{9,19,20}$ Masa paruh yang sangat panjang merupakan akibat dari kecepatan eliminasi yang rendah. Pada dewasa, umumnya kafein diubah menjadi xantin demetilasi dan asam metilurat oleh hati. Pada neonatus, kafein diekskresi dalam urin dalam bentuk utuh. Hal ini merupakan akibat defisiensi sistem enzim sitokrom P-448/450. ${ }^{10}$ Batas terapeutik kafein yang dapat diterima untuk pengobatan apne adalah 5-20 ug/ ml. 1,4,19,21,22 Toksisitas jarang dijumpai. Terapi dimulai dengan $10 \mathrm{mg} / \mathrm{kg}$ berat badan loading dose kafein basa (20 mg kafein sitrat), diikuti dengan dosis pemeliharaan sebesar 2,5-5 mg/kg berat badan/hari kafein basa, 1 kali perhari. ${ }^{1,4,8,9,20-23}$ Konsentrasi rendah sebesar 3-4 mg/L dapat mengontrol serangan apne. Bayi-bayi yang gagal memberi respons dengan dosis ini harus mendapatkan peningkatan dosis dengan monitoring konsentrasi plasma. Pengukuran nilai plasma dilakukan pada hari kelima atau ke-enam setelah loading dose ${ }^{11,22,23}$ Dari beberapa studi menunjukkan penurunan insidens efek samping pada terapi kafein. ${ }^{2}$ Tidak dijumpai toksisitas terhadap kardiovaskular, SSP, dan gangguan gastrointestinal sampai konsentrasi $50 \mathrm{mg} / \mathrm{L}^{20}$

\section{Teofilin}

Pada bayi baru lahir, imaturitas sistem enzim sitokrom P-448/450 memungkinkan terjadinya metilasi teofilin menjadi kafein. ${ }^{8,9,20,21}$ Aktifitas teofilin pada apne neonatus bisa diakibatkan oleh konversi ini. Perkiraan usia kapan maturasi metabolik terjadi, tidak pasti, tetapi bayi usia 16 bulan tidak menunjukkan metilasi menjadi kafein. Terdapat korelasi antara usia dan klirens teofilin plasma. ${ }^{21}$ Kafein dibersihkan dari plasma pada bayi baru lahir lebih lambat dibandingkan teofilin yang mempunyai masa paruh berkisar $20-30$ jam, ${ }^{1,11,19,20}$ sehingga kafein dapat berakumulasi dalam plasma pada terapi teofilin yang berlanjut. ${ }^{17,24}$

Efek merugikan teofilin pada neonatus antara lain takikardia, hiperglikemia, natriuresis, hiperrefleksi, jitternes, intoleransi gastrointestinal, dan melemahnya tekanan sfinkter esofagus dengan peningkatan refluks gastroesofagus. Hubungan antara teofilin dan terjadinya necrotizing enterocolitis (NEC) diduga hanya anekdot, peranan teofilin pada patogenesis NEC belum jelas. ${ }^{12,21}$ Meskipun demukian Lane, ${ }^{12}$ pada penelitian terhadap 12 bayi prematur melaporkan bayi yang mendapat xantin mengalami insidens NEC yang sedikit lebih tinggi (9\%) dibandingkan tanpa xantin (5\%).

Batas terapeutik teofilin yang dapat diterima pada pengobatan apne sebesar 5-15 ug/mL., ${ }^{1,414}$ Loading dose $5 \mathrm{mg} / \mathrm{kg}$ berat badan teofilin secara parenteral atau per oral diikuti 12 jam kemudian dengan dosis $2 \mathrm{mg} / \mathrm{kg}$ berat badan/kali setiap $12 \mathrm{jam} .{ }^{20,21}$ Konsentrasi plasma metilxantin yang berakumulasi (teofilin dan kafein) harus ditentukan ${ }^{17,25}$ dan dipertahankan pada level kurang dari $20 \mathrm{ug} / \mathrm{mL}$ untuk menghindarkan toksisitas. ${ }^{16,21,23}$ Denyut jantung yang melebihi 180 kali permenit atau sampai 
muntah dipilih sebagai bukti langsung untuk menentukan toksisitas. Bila hal ini terjadi, dosis diturunkan. ${ }^{25}$ Nilai serum harus dievaluasi 48-72 jam setelah terapi pemeliharaan dimulai. ${ }^{20}$

Beberapa zat yang dapat menimbulkan Interaksi farmakoterapetik dengan metilxantin, akan menurunkan klirens teofilin, adalah antagonis $\mathrm{H} 2$ (simetidin dapat meningkatkan konsentrasi teofilin sampai dengan 50\% setelah dosis pertama), antagonis ß-2, antibiotik quinolone, dan eritromisin. Golongan obat yang meningkatkan klirens teofilin dan mengakibatkan konsentrasi dalam serum yang lebih rendah,yaitu agonis $B-2$, barbiturat, rifampisin, perokok primer atau sekunder. ${ }^{26}$

\section{Lama terapi}

Terapi metilxantin pada apne biasanya dilanjutkan sampai bayi mencapai usia pascakonsepsi $32-37$ minggu, dan episode apne menghilang. ${ }^{23}$ Bayi yang tidak apne secara klinis setelah 5-7 hari mendapatkan teofilin atau kafein pada dosis terapeutik, dapat dipulangkan dan setelah 2-3 minggu kemudian obat dihentikan..$^{13,22}$

\section{Kesimpulan}

Teofilin dan kafein merupakan obat yang paling sering diberikan untuk mengatasi episode apne idiopatik. Pemberian obat tersebut harus disertai monitoring konsentrasi plasma dan klinis yang hati-hati untuk mencegah toksisitas.

\section{Daftar Pustaka}

1. Apnea. Diambil dari URL : http://neonatal.peds.washington.edu/NICU-weblapneastm

2. Caffeine versus theophylline for apnea in preterm infants (Steer PA, Henderson-Smart DJ). Diambil dari URL : http://www.nichd.nih.gov/cochrane/Steer/Steer.HTM

3. Thilo EH, Rosenberg AA. The newborn infant. Dalam: Hay WW, Hayward AR, Levin MJ, Sandheimer JM, penyunting. Current pediatric diagnosis \& treatment. Edisi ke-15. New York: Lange medical book, 2001. h. 30-1.

4. Kliegman RM. Respiratory tract disorders. Dalam: Behrman RE, Kliegman RM, Jenson HB,penyunting. Nelson textbook of Pediatrics. Edisi ke-16. Philadelphia: Saunders, 2000. h. 497-8.
5. Menendez AA, Alea OA, Beckerman RC. Control of ventilation and apnea. Dalam: Goldsmith JP, Karotkin $\mathrm{EH}$, penyunting. Assisted ventilation of the neonate. Edisi ke-3. Philadelphia: Saunders, 1996. h. 69-73

6. Apnea of prematurity. Diambil dari URL: http:// www.Ipch.org/DiseaseHealthInfo/HealthLibrary/respirel apneapre.html

7. Bauer J, Maier K, Liderkamp O, Hentschel R. Effect of caffeine or oxygen consumption and metabolic rate in very low birth weight infants with idiopathic apnea. Pediatrics 2001; 107:660-3.

8. Corbet A. Respiratory disorders in the newborn. Dalam: Chernick V, Kendig EL, penyunting. Kendig's disorder of the respiratory tract in children. Edisi kelima. Philadelphia: Saunders, 1990. h. 271-2

9. Milner AD. Apnoea and bradycardia. Dalam: Rennie JM. Roberton NRC, penyunting. Textbook of neonatology. Edisi ke-3. Edinburgh: Churchil livingstone, 1999.h.630-5

10. Gibson E. Apnea. Dalam: Spitzer AR, penyunting. Intensive care of the fetus and neonate. St Louis: Mosby, 1996. h. 470-7

11. Bairam A, Boutroy MJ, Badonnel Y, Vert P. Theophylline versus caffeine: Comparative effects in treatment of idiopathic apnea in the preterm infant. J Pediatr 1987; 110:636-9.

12. Lane AJB, Coombs RC, Evans DH, Levin RJ. Effect of caffeine on neonatal splanchnic blood flow. Arch Dis Child 1999; 80:128-9.

13. Apnea of prematurity. Diambil dari URL: http:// www.med.umich.edu/1libr/pa/pa-apnea-hhg.htm

14. Aldoretta PW, Spedale SB. Care of the newborn. Dalam: Merenstein GB, Kaplan DW, Rosenberg AA, penyunting. Handbook of pediatrics. Edisi ke-18. London: Prentice Hall, 1997. h. 146-7.

15. Rall TW. Central nervous system stimulants (continued). Dalam: Gilman AG, Goodman LS, Gilman A, penyunting. Goodman and Gilman's. The pharmacological basis of therapeutics. Edisi ke-6. New York: Macmillan; 1980. h. 592-600.

16. Sunaryo. Perangsangan susunan saraf pusat. Dalam: Ganiswara SG penyunting. Farmakologi dan terapi. Jakarta: FKUI, 1995. h. 226-33.

17. Bory C, Baltassat P, Porthault M, Bethenod M, Frederich A, Aranda JV. Biotransformation of theophylline to cafffeine in premature newborn. Lancet 1978; 2:1204-5.

18. Dascalova LC, Aujard Y, Gaultier C, Rajguru M. Sleep oganization is unaffected by caffeine in premature infants. J Pediatr 2002; 140:766-70. 
Sari Pediatri, Vol. 6, No. 3, Desember 2004

19. Rennie JM. Pharmacology. Dalam: Rennie JM, Roberton NRC, peyunting. Texbook of neonatology. Edisi ketiga. Edinburgh: Churchill Livingstone, 1999. h. 425-33.

20. Goetzman BW, Milstein JM. Pharmacologic adjunct I. Dalam: Goldsmith JP, Karotkin EH, penyunting. Assisted ventilation of the neonate. Edisi ketiga. Philadelphia: Saunders, 1996. h. 301-2.

21. Ackerman VL, Harris JM. Pharmacology of the respiratory system. Dalam: Fuhrman BP, Zimmerman JJ, penyunting. Pediatric critical care. St louis: Mosby, 1992. h. 417-8.

22. Neonatal apnea. Diagnosis and management. Diambil dari URL: http://www.peds.umn.edu/divisions/neonatology/ spnicaltext $19 . \mathrm{html}$
23. Teaching files: Evaluation and management of apnea of prematurity. Diambil dari URL: http://www. neonatology.org/syllabus/apnea.html

24. Chemtob S, Aranda JV. Pharmacology in the fetus and newborn. Dalam: Spitzer AR, peyunting. Intensive care of the fetus and neonate. St. Louis: Mosby, 1996. h. 185-6

25. Shannon DC, Gatay F, Stein IM, Roger MC, Todres ID, Moylan FMB. Prevention of apnea and bradycardia in low-birth weight infants. Pediatrics 1975; 55:589-91.

26. Banner W, Vernon DD. Intervention for specific toxins. Dalam: Fuhrman BP, Zimmerman JJ, penyunting. Pediatric critical care. St. Louis : Mosby, 1992. h. 1134 